One of us (P. N. V.) thanks the Council of Scientific and Industrial Research, Government of India, for the award of a junior research fellowship.

P. N. Viswanathay

P. S. KRISHNAN

Division of Biochemistry,

Lucknow University, India.

${ }^{1}$ Racker, E., Nature, 175, 249 (1955).

' Racker, E., and Schroeder, E. A. R., Arch. Biochem. Biophys.. 74, $326(1958)$.

${ }^{3}$ Chakrayorty. M., Chakrabortty, H. C., and Burma, D. P., Arch. 4 Smillie, R. M., Nature, 187, 1024 (1960)

'Lowry, O. H., Rosebrough, N. J., Farr, A. L., and Randall, R. J., J. Biol. Chem. 193, 265 (1951).

\section{5-Nucleotidase of Rat Pancreatic Islets and Ducts in Normal and in Hyperten- sive Rats}

In this communication we describe the adenosine5-monophosphatase (5-nucleotidase) demonstrable within rat pancreatic islets and ducts after incubation with adenosine-5-monophosphate at $p \mathrm{H} \mathbf{7 \cdot 8}$.

Pearse ${ }^{1}$ has pointed out that it is possible to gain valuable information about the distribution of certain substrate-specific tissue phosphatases by using the technique in ref. 2 . In this method adenosine-5monophosphate is used as substrate to denote the activity of the specific 5-nucleotidase of Reis ${ }^{3-5}$. Incubation with the substrate at $p H \quad 7.5$ allows a clearer distinction from non-specific phosphatases than was found ${ }^{6}$ at $p \mathrm{H} 9 \cdot 2$.

Several authors have investigated the distribution of substrate-specific enzymes in the pancreatic islets of the rat. Their observations have been reviewed ${ }^{7-8}$ So far as we are aware, a 5-nucleotidase active at $p \mathrm{H}$ 7.8 has not previously keen demonstrated by the technique in ref. 2 within the pancreatic islets and ducts. This may be because of the known problems of diffusion at $p \mathrm{H} 7 \cdot \overline{\mathrm{y}}$, a difficulty which it is believed has been overcome by adopting the slightly higher $p \mathrm{H}$ of $7 \cdot 8$.

Fresh pancreas was collected from normal adult male Wistar rats and from adult male rats with hypertension developing under the influence of cortexone and sodium ${ }^{10}$. The pancreatic tissue was fixed immediately after removal in three changes of acetone at $4^{\circ} \mathrm{C}$. for $24 \mathrm{hr}$. Material was doubleombeddəd in celloidin and paraffin; paraffin sections cut as thinly as possible were stored until use in plastic bags containing ealcium chloride in the refrigar ator at $4^{\circ} \mathrm{C}$. Sections were incubated with sodium B-glycerophosphate and with the adenosine 5-monophosphate substrate of Pearse ${ }^{1}$ both at $p H 7.8$ and at $p \mathrm{H} 9 \cdot 2$. Experiments showed that the optimum results were obtained by incubation with adenosine-5monophosphate at $p \mathrm{H} 7.8$ for $3 \mathrm{hr}$. at $37^{\circ} \mathrm{C}$.

With this technique it was possible to demonstrate an adenosine-5-monophosphatase within the pancreatic islet cells and within the cells of the small pancreatic ducts. No reaction was detected within the glandular acini, islets or ducts incubated with sodium $\beta$-glycerophosphate at $p \mathrm{H} 7.8$ and at $p \mathrm{H} 9.2$ or with adenosine-5-monophosphate at $p H$ 9.2. Enzyme inhibition was demonstrated by adding $10 \mathrm{ml}$. of a millimolar solution of nickel chloride to each $40 \mathrm{ml}$. substrate. Inhibition was not detected when only $1 \mathrm{ml}$. of millimolar nickel chloride was added. and in neither instance did the inhibitory concentration differ from that observed with non-specific phosphatase at $p \mathrm{H} 9 \cdot 2$.
The distribution of the enzyme did not differ in normal or in hypertensive animals. It was not possible to determine whether the enzyme was concentrated principally within $\alpha$-or $\beta$-cells although diffusion of precipitated calcium phosphate at $p \mathrm{H} 7 \cdot 8$ is apparently less rapid than at $p \mathbf{H} 7 \cdot 5$. It appears possible that the possession of this enzyme by both islet cells and by ducts is a reflexion of the common developmental origin of these structures.

\section{J. A. R. FRIEND}

Pathology Department,

D. L. Gardner

University of Edinburgh,

Teviot Place, Edinburgh, 8.

${ }^{1}$ Pearse, A. G. E., Histochemistry, Theoretical and Applied, second ed., 412, 874 (Churchill, London, 1960).

${ }^{2}$ Pearse, A. G. E., and Reis, J. L., Biochem. J., 50, 534 (1952).

${ }^{3}$ Reis, J. L., Enzymologia, 2, 110 (1937).

${ }^{4}$ Reis, J. L., Bull. Soc. Chim. Biol., Paris, 22, 36 (1940).

${ }^{5}$ Reis, J. L., Proc. Biochem. Soc., Biochem. J., 46, xxi (1950).

- Gomori, G., Proc. Soc. Exp. Biol. N.Y., 72, 449 (1949).

"Gomori, G., Microscopic Histochemistry (Chicago Univ. Press, 1952).

${ }^{8}$ Lison, L., Histochimie et Cytochimie animales, 2nd ed., 514 (GauthierVillars, Paris, 1853).

${ }^{9}$ Schätzle, W., Acta histochem., Jena, 6, 93 (1958).

${ }^{10}$ Gardner, D. L., Brit. J. Exp. Path., 41, 60 (1960).

\section{Ultra-Rapid Fluorescent Labelling of Proteins}

A Nover method for the fluorescent labelling of proteins has been described recently which involved treatment of a protein solution with an active labelling dye dispersed on diatomaceous earth or other inert materials ${ }^{1}$. This modification afforded a considerable saving in time and minimized protein denaturation as compared with earlier techniques. The experiments reported here constitute a further improvement of this procedure which obviates time-consuming dialysis and permits fluorescent labelling of protein solutions, removal of hydrolysed or unreacted dye and change of buffer as well as $p \mathbf{H}$ in less than $30 \mathrm{~min}$.

The method has been used successfully with fluoresceinisothiocyanate, 'Lissamine rhodamine B200' chloride and dimethylaminonaphthalene sulphonylchloride on 'Celite' or cellulose powder (available from the California Corporation for Biochemical Research) and is illustrated by the following example. A mixture of $2 \mathrm{ml}$. of rabbit serum and $2 \mathrm{ml}$. of $0.05 \mathrm{M}$ sodium carbonate-bicarbonate buffer of $p \mathrm{H} 8.5$ is shaken for approximately $3 \mathrm{~min}$. (adequate labelling is obtained in as little as $10 \mathrm{sec}$.) with $5-10 \mathrm{mgm}$. of 'Celite' con. taining approximately 10 per cent of fluoresceinisothiocyanate. The mixture is now centrifuged for $3 \mathrm{~min}$. and the supernatant allowed to flow into a column $(2.8 \times 18 \mathrm{~cm}$.) of 'Sephadex G25' (Pharmacia Uppsala, Sweden). The latter is prepared in advance of the experiment by pouring a slurry of 'Sephadex' into a column half filled with water, allowing the gel to settle and washing afterwards with several column volumes of $0.02 M$ sodium phosphate buffer of $p \mathbf{H} 6.5$. The column is now developed with phosphate buffer $(0.02 M, p H 6.5)$, care being taken not to disturb the exposed gel surface. A spectacular separation of the fluorescent proteins from inert dye is observed almost immediately. The stronger yellow protein band proceeds rapidly down the column while the weak inert dye band remains very close to the point of application. The labelled protein is collected almost quantitatively in approximately 6-8 $\mathrm{ml}$. of effluent which represents an increase in volume of only 50-100 per cent. Elution of the fluorescent 